\title{
Recent Trend of the Decrease in Mean Birthweights of Infants in the Western Provinces of Cifu Prefecture, Japen
}

\author{
Atsushi Hioki
}

\begin{abstract}
The mean birthreight has decreused recently in Japan. The author assessed the etiology of this: trend by compuring the birthweight durthg the years $1983-1984$ and 1993-1994 in Central Japen. All bith certiticates of 3767 and 3423 infants were avallable for 1983-1984 and 1993-1994, respecthely. The mean birthweight decreased from $3165 \mathrm{~g}$ to $3128 \mathrm{~g}$. The proportion of first Infants whos mean blithweight decreased more than that of the other infants inoreased from 41.0\% to 47.t\%. Comparison and muttivariate andysis revealed the ma'n ceuse of decreased birthwoight as a decreass of the mean birthweight of first infants and changes of the proportion of bith arder. Influences of the increases in the proportion of multiple births and that of low blrthweight infants to the decrease of mean birthweight were smalt. The moan birthwelght of infarts who were bom in public hospltats was lower than that of infants born in clinics, private hospltals, and others. The proportion of low birthweight infants wes also highost among the infants bom in public hospitals. Theee results indicate that pregnant women with high riak factors are more likely to be referred to the care of public hospltals. J Epidemiol, 1997; 7 ; 232-237.
\end{abstract}

birthweight, infant, birth certificate, birth order, birth place

Acconting to vital statistics in Japen, the mean birthweight of infants has decreased gradually, from $3.24 \mathrm{~kg}$ for males and $3.15 \mathrm{~kg}$ for females at peak in 1975 to $3.20 \mathrm{~kg}$ and $3.12 \mathrm{~kg}$ in 1985 , and $3.12 \mathrm{~kg}$ and $3.04 \mathrm{~kg}$ in $1994^{\mathrm{v}}$. However. the reasons for these trends are not obvious. It is reported that bow birthweight results from preterm delivery or intrauterine wowth retandation 23. Several suxdies revealed that infant's sex, matemal age, marital status, ethnicity, education, carrent employment, smoking matemal height, matermal pre-pregnancy weight, gestational weight gain, parity, previous stillbirth. alcohol consumption, inadequate nutrition during gestation, and spcioeconomic stans ane associated with variations in intraurterine growth retardation ${ }^{40}$. Risk factors for preterm birth inchude ethricity, single marital stans, low socioeconomic stas, previous low birthweight or preterm delivery, multiple second trimester spontaneous abontions, in vitro fertilization pregnancy, placental abnommalities, gestational bleeding. cervical and uterine anomalies, multiple gestations, and smoking . Pregatunt Japanese women are counseled nox to become overweight to prevent toxemia of presnancy ${ }^{40}$, so the biathweight of infants may become a little lighter. The author alssumed that the decrease of the mean birthweight of infants resulted from (1) an increase in the multiple pregnancy rate (2) in increase in the proportion of live births of kw birthweight infants (LBW), (3) an increase in the propontion of first chidren whose birthweight is lighres than that of the cthors, (4) a decrease in postterm labor, and (5) bealth/dietary gatidance in prevent toxemia of pregnancy. The anthor atcempted to clarify the determinin's of the decrease in mean bithweight of infents and the consequent need for public health services.

\section{Mathos}

Ibi-Motosit district, the anea of this study, is bocated in the westem provinces of Gifu Prefectune, central laptin. This district consists of residentid towns, itpopulated villages and intermatiate towns. In 1994, this district had a population of 160,000 in a $10596 \mathrm{~km}$ area The binth rate in 1994 in this district was 10.7 per thousand population, a fitte higher than that in Japan (10.0)

Bith certificate dita (only livetirths) in this district from all 3767 and 3423 births during 1983-1984 and 1993-1994, respectively, were checked for mother's age at delivery, marital stathes. nintionality, multiplicity, live birth onder. past history of abotion or stillbirth, birth place, gestational age, infant sex, and birth-

Recelved Jamuary 10, 1997 ; accepted March 21,1997.

Medicad Treadnent Management Division, Public Haalth and Erwionment Depertment, Gitu Prefectural Govemment, Gifu, Japen. Formerly: Gliu Prefectural Ohno Publlc Health Center, Gliu, Japen.

Address for comespondence, Atsushi H"loki, Medical Treatment Management Division, Putblic Heeith and Environment Depertment, Gitu Prefectural Govermment, Gifu, 500-70 Japan. 
weighte. Bitth place was categarized into clinics, private boeptals, public hospitals, midwifery home, home, and others In Japen, clinics and hospinals are defined as medical instintous with fewer then 20 beds and those with 20 bods $0 x$ mure, respectively. In many cases, public hospinals have more equipmenl and more staff. Gestational age is expressed as full weeks of pregnnary besed on the date of first day of mother's last menstrual period according to the International Classification of Diseraxs. Ninth Revision (ICD-9). No information was collectod about the use of ceserean section from birth certificate data

Fustly, percentage distributions of birthweight, mean birthweight, and proportion of LBWI wexe compared on all births dota between the periods 1983-1984 and 1993-1994 by nationality of parents, multiplicity, past history of abortion on stillbirth, and infent sex. They were analyzed by $x^{2}$ test in contingency tablex, non-paired t test, and by one-way analysis of variance (ANOVA), followed by Dunnett's ttest when a difference was found by ANOVA. The influences of the changes in the per. centage distribution and metn birthweight of each category on the decrease of mean binhweight were also determined.

Next, mean birthweight of single birth infants whose parents were both lapanese (3732 and 3351 infants in 1983-1984 and 1993-1994. respectively) were calculated by gestational age and live bith oder in 1983-1984 and 1993-1994. This study smalyzed data on infents whose parents were both Japanese to exclude the influence of mac on birthweight ${ }^{2+4}$. Data on illegitimete infants ( 9 infants in 1983-1984 and 14 in 1993-1994) are not included in the malysis because the nationality of their fathers are onlnown. Mean birthweights were compared by
ANOVA followed by Durnett's t-test.

Stepwise regression analyses (F-to-enter $=4.000$, F-toremove $=3.996$ ) were performed jointly and separately for both periods to estimate the factors affecting infant birthweight on the data of single birth infants whose perents were both Japanese. Birthweight was used as the dependent variable, and maternal age, past history of fetal death. gestationel age, infant sex, bith order, and perind of birth were the independent varables. In the analysis, scores for mother's age were assigned separately for age class as follows: $<0$ years, 20-34 years and $\geq 35$ years (yes $=1, n O=0$, nespectively).

To investigate the perinatal medical care system characteristics, mean birthweight, percentage distributions of birthweight and gestational age were compared by birh place on the data of single birth infants whose parents were both Japanese, using ANOVA followed by Dumetr's t-kest and $\chi^{2}$ test

\section{RESULTS}

The mean birthweight (ISD) of all infants decreased from $3165( \pm 429) \mathrm{g}$ in 1983-1984 to 3128 ( \pm 435$) \mathrm{g}$ in 1993-1994 (p<0.001; Table 1). The ovendl incidence of LBWI $(\angle 2500 \mathrm{~g}$ ) was 5.1\% in 1983-1984 and 6.1\% in 1993-1994 (not significantly different); however, the incidence of very low birthweight infants $(<1500 \mathrm{~g}$ ) increased from $0.2 \%$ to $0.5 \%$ (p<0.05). Fig. 1 shows the birthweight distribution in 1983I984 and 1993-1994. The distribution curve of birthweights between $3000 \mathrm{~g}$ and $4000 \mathrm{~g}$ shifted downwand in 1993-1994 compared to 1983-1984. The incidence of mulhiple preggrancy

Table 1. Cheracteristics of all birtbs in 1983-1984 and 1993-1994 in the westem provinces of Gifu Prefecture, Japan.

\begin{tabular}{|c|c|c|c|c|c|c|}
\hline & \multicolumn{2}{|c|}{ Number (\$) } & \multicolumn{2}{|c|}{ Mean ( \pm SD) birthweight (g) } & \multicolumn{2}{|c|}{ Proportion of LBWI* (\%) } \\
\hline & $1983-1984$ & $1993-1994$ & $1983-1984$ & $1993-1994$ & $1983-1984$ & $1993-1994$ \\
\hline $\begin{array}{l}\text { Nalionality of partents } \\
\text { Both Jepanes } \\
\text { 2l Foreigner } \\
\text { Unmarried Japanese }\end{array}$ & $\begin{array}{r}3758(99.8) \\
0(0.0) \\
9(0.2)\end{array}$ & $\begin{array}{r}3392(99.14) \\
17(0.5) \\
14(0.4)\end{array}$ & $\begin{array}{c}3166 \pm 429 \\
- \\
2942 \pm 419\end{array}$ & $\begin{array}{l}3128 \pm 435 \\
3118 \pm 515 \\
3147 \pm 327\end{array}$ & $\begin{aligned} 5.1 \\
- \\
11.1\end{aligned}$ & $\begin{array}{r}6.1 \\
11.8 \\
0.0\end{array}$ \\
\hline $\begin{array}{l}\text { Muloiplicity } \\
\text { Single } \\
\text { Multiple }\end{array}$ & $\begin{array}{r}3741(99.3) \\
26(0.7)\end{array}$ & $\begin{array}{r}3382\left(98.8^{+}\right) \\
41\left(1.2^{+}\right)\end{array}$ & $\begin{array}{l}3170 \pm 424 \\
2426 \pm 511\end{array}$ & $\begin{array}{l}3135 \pm 429 \\
2528 \pm 446\end{array}$ & $\begin{array}{r}4.8 \\
53.8\end{array}$ & $\begin{array}{r}5.7 \\
39.0\end{array}$ \\
\hline $\begin{array}{l}\text { Past history of abortion or stillbirth } \\
\text { With } \\
\text { Without }\end{array}$ & $\begin{array}{r}42(1.1) \\
3725(98.9)\end{array}$ & $\begin{array}{r}36(1.1) \\
3385(98.9)\end{array}$ & $\begin{array}{l}2982 \pm 542 \\
3167 \pm 427\end{array}$ & $\begin{array}{l}3053 \pm 672 \\
3128 \pm 431\end{array}$ & $\begin{array}{r}16.7 \\
5.0\end{array}$ & $\begin{array}{r}13.9 \\
6.0\end{array}$ \\
\hline $\begin{array}{l}\text { Infunt sex } \\
\text { Male } \\
\text { Female }\end{array}$ & $\begin{array}{l}\text { I904 (50.5) } \\
\text { I863 (49.5) }\end{array}$ & $\begin{array}{l}1768(51.7) \\
1655(48.3)\end{array}$ & $\begin{array}{l}3212 \pm 440 \\
3117 \pm 412\end{array}$ & $\begin{array}{l}3168 \pm 436^{ \pm} \\
3085 \pm 429^{t}\end{array}$ & $\begin{array}{l}4.3 \\
5.9\end{array}$ & $\begin{array}{l}5.7 \\
6.5\end{array}$ \\
\hline Totel & $3767(-)$ & $3423(-)$ & $3165 \pm 429$ & $312 B \pm 435^{i}$ & 5.1 & 6.1 \\
\hline
\end{tabular}

" Low birthweight infants. " $p<0.05$ : ${ }^{+} p<0.01:$ 'p<0.001 ws. 1983-1984 
Table 2. Mean birthweight \pm SE (number) of infants by gestntional age in 1983-1984 end 1993-1994, (single births whase parents were both Japanese)

\begin{tabular}{|c|c|c|c|c|c|c|c|c|}
\hline \multicolumn{2}{|l|}{ Sex } & \multirow{2}{*}{$\frac{s 36 \text { weeks }}{2463 \pm 67}$} & \multirow{2}{*}{$\frac{37 \text { weeks }}{2984 \pm 34}$} & \multirow{2}{*}{$\frac{38 \text { woeks }}{3125 \pm 19}$} & \multirow{2}{*}{$\frac{39 \text { weeks }}{3249 \pm 16}$} & \multirow{2}{*}{$\frac{40 \text { weeks }}{3339 \pm 17}$} & \multirow{2}{*}{$\begin{array}{l}41 \text { weeks } \\
3374 \pm 27\end{array}$} & \multirow{2}{*}{$\frac{242 \text { weeks }}{3451 \pm 47}$} \\
\hline Male & 1983-1984 & & & & & & & \\
\hline & & & (138) & $(356)$ & & $(474)$ & & \\
\hline & $1993-1994$ & $\begin{array}{l}2268 \pm 71^{+} \\
(62)\end{array}$ & $\begin{array}{l}2866 \pm 35^{*} \\
(99)\end{array}$ & $\begin{array}{l}3064 \pm 19 * \\
(320)\end{array}$ & $\begin{array}{l}3211 \pm 16 \\
(536)\end{array}$ & $\begin{array}{l}3292 \pm 17 \\
(501)\end{array}$ & $\begin{array}{l}3354 \pm 30 \\
(171)\end{array}$ & $\begin{array}{l}3237 \pm 74 \\
\text { (39) }\end{array}$ \\
\hline \multicolumn{2}{|c|}{ Female 1983-1984 } & $\begin{array}{l}2485 \pm 65 \\
(61)\end{array}$ & $\begin{array}{l}2882 \pm 38 \\
(102)\end{array}$ & $\begin{array}{l}3019 \pm 22 \\
(274)\end{array}$ & $\begin{array}{l}3114 \pm 15 \\
(5 \%)\end{array}$ & $\begin{array}{l}3227 \pm 16 \\
(523)\end{array}$ & $\begin{array}{l}3252 \pm 27 \\
(222)\end{array}$ & $\begin{array}{l}3271 \pm 36 \\
(76)\end{array}$ \\
\hline & 1993-1994 & $\begin{array}{l}2025 \pm 115^{\ddagger} \\
\text { (99) }\end{array}$ & $\begin{array}{l}2895 \pm 36 \\
\text { (76) }\end{array}$ & $\begin{array}{l}2987 \pm 19 \\
(287)\end{array}$ & $\begin{array}{l}3113 \pm 17 \\
(499)\end{array}$ & $\begin{array}{l}3175 \pm 16^{*} \\
(468)\end{array}$ & $\begin{array}{l}3255 \pm 28 \\
(216)\end{array}$ & $\begin{array}{l}3272 \pm 56 \\
\text { (34) }\end{array}$ \\
\hline
\end{tabular}

*po0.05; "p<0.01; " po0.001 vg. 1983-1984

Table 3. Mean birthweight $\pm S E$ (number) of infants by gestarional age and live birth ocder. (single births whose parents were both Japanese)

\begin{tabular}{|c|c|c|c|c|c|c|}
\hline & Birth onder & 536 weets & 37-39 weeks & 40-41 weeks & $\geq 42$ werks & Total \\
\hline 1983-1984 & $\begin{array}{l}\text { Ist child } \\
\text { 2nd child } \\
\geq 3 \text { rd child } \\
\text { Towal }\end{array}$ & $\begin{array}{l}2429 \pm 84(57) \\
2529 \pm 59(59) \\
2432 \pm 128(21) \\
2473 \pm 47(137)\end{array}$ & $\begin{array}{l}3061 \pm 14(745) \\
3145 \pm 13(855) \\
3170 \pm 19(409) \\
3119 \pm 9(2009)\end{array}$ & $\begin{array}{l}3241 \pm 15(657) \\
3307 \pm 16(514) \\
3378 \pm 26(268) \\
3290 \pm 10(1439)\end{array}$ & $\begin{array}{l}3910 \pm 40(75) \\
3377 \pm 51(48) \\
3471 \pm 90(24) \\
3358 \pm 30(147)\end{array}$ & $\begin{array}{l}3127 \pm 11(1534) \\
3185 \pm 11(1476) \\
3236 \pm 16(722) \\
3171 \pm 7(3732)\end{array}$ \\
\hline $1999-1994$ & $\begin{array}{l}\text { 1st child } \\
\text { 2ind child } \\
\text { 23nd child } \\
\text { Total }\end{array}$ & $\begin{array}{l}2098 \pm 96(50) \\
2294 \pm 99(34) \\
2158 \pm 141(17) \\
2174 \pm 63(101)\end{array}$ & $\begin{array}{l}3016 \pm 13(794) \\
3164 \pm 12(890) \\
3049 \pm 31(133) \\
3091 \pm 9(1817)\end{array}$ & $\begin{array}{l}3205 \pm 13(697) \\
3287 \pm 19(456) \\
3344 \pm 27(203) \\
3253 \pm 10(1356)\end{array}$ & $\begin{array}{l}3327 \pm 58(39) \\
3325 \pm 107(20) \\
3504 \pm 116(14) \\
3360 \pm 48(73)\end{array}$ & $\begin{array}{l}3078 \pm 11(1581) \\
3178 \pm 12(1235) \\
3205 \pm 19(535) \\
3135 \pm 7(3351)\end{array}$ \\
\hline Mean difference & $\begin{array}{l}\text { Ist child } \\
\text { 2nd child } \\
23 \text { rd child } \\
\text { Total }\end{array}$ & $\begin{array}{l}-332^{\ddagger} \\
-235^{\ddagger} \\
-274^{\sharp} \\
-299^{\ddagger}\end{array}$ & $\begin{array}{l}-45^{*} \\
+19 \\
-121^{4} \\
-28 *\end{array}$ & $\begin{array}{l}-36 \\
-20 \\
-35 \\
-37\end{array}$ & $\begin{array}{l}+17 \\
-52 \\
+34 \\
+2\end{array}$ & $\begin{array}{l}-49^{4} \\
-6 \\
-31 \\
-36^{\ddagger}\end{array}$ \\
\hline
\end{tabular}

†p 00.05: ${ }^{+}$<0.01: ${ }^{\mp}$ p<0.001 vs. 1983-1984

Fin 1. Distribution of birth weight of all infants during the periods 1983-1984 (e) and 1993-1994 (O).

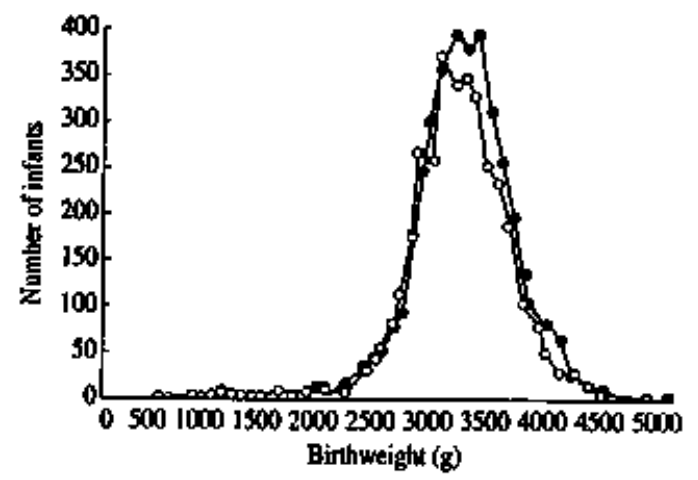

was 0.35\% in 1983-1984 and 0.59\% in 1993-1994 (not significant), but the propotion of multiple birth infarts increased sig- nificently from $0.69 \%$ to $1.20 \%$ (p<0.05; Table 1 ). The mean birthweight of multiple birth infants tended to increase in 1993-1994 (not significant). Mean pestational gaes (tSD) were 39.15 ( \pm 1.59 ) weeks in 1983-1984 and 39.13 ( \pm 1.57 ) weeks in 1993-1994 (not significant). The proportion of posttem labor (242 weeks' gestation) decreased fom 3.9\% in 1983-1984 to 2.3\% in 1993-1994 (p<0.001). The proportion of preterm infants ( 637 weeks' gestation) was not significandy diffienert: $3.8 \%$ in 1983-1984 and 3.1\% in 1993-1994. The propotion of very patem births ( $\alpha 2$ weeks' gestation) was $0.4 \%$ for both ine periods. The mean age (tSD) of mothers increased from $27.3( \pm 3.6)$ years old in 1983-1984 to $28.0( \pm 3.9)$ years old in 1999-1994 (p<0.001). The proportion of mothers 30 years ok1 and over increased significantly in 1993-1994 (pela.001). The proportion of parents at least one of whom was foreign increased in 1993-1994. The proportion of first child increased from 41.0\% in 1983-1984 to 47.1\% in 1993-1994 (p40.001). The percentage of pregnant women with past history of abor- 
Table 4, Results of stepwise regression snelysis with birthweight as the outcome and maternial age, past history of fatal death, gestational age, infant sex, birth order, and period of bith as explanatory variables on the data of single births whose parenis were both Japanese.

\begin{tabular}{lcrrr}
\hline Independent variables & Partial regression coeficient & SE & \multicolumn{1}{c}{ Standardized regression coefficient } & P value \\
\hline Mother<20 years old & -107.880 & 53.188 & -0.021 & 0.0426 \\
Gestational age (wecks) & 126.186 & 2.860 & 0.460 & 0.0001 \\
Male & 106.282 & 8.889 & 0.125 & 0.0001 \\
First infant & -110.187 & 9.003 & -0.128 & 0.0001 \\
1993-1994 & -28.502 & 8.906 & -0.033 & 0.0014 \\
lntercept & -1778.95 & - & - & - \\
R & 0.485 & - & - & 0.0001 \\
\hline
\end{tabular}

Table 5. Numbers $(\%)$ of infants (single births whose parents were both Japacese) by birthweight and birth place.

\begin{tabular}{|c|c|c|c|c|c|c|c|c|c|c|}
\hline \multirow{2}{*}{ Birth place } & \multicolumn{5}{|c|}{ 1983-1984 } & \multicolumn{5}{|c|}{$1993-1994$} \\
\hline & $<1500 \mathrm{~g}$ & $1500-2499 g$ & $2500-3999=$ & $24000 \operatorname{g} \chi^{2}$ & int & $<1500 \mathrm{~g}$ & $1500-2499 g$ & $2500-3999 \mathrm{~g}$ & $24000 \mathrm{~g} x^{2}$ & test \\
\hline Clinic & $3(0.1)$ & $100(4.3)$ & $2167(92.8)$ & $64(2.7)$ & NS & $3(0.1)$ & $104(4.7)$ & $2062(93.0)$ & $4 B(2.2)$ & $\uparrow$ \\
\hline Private hospital & $0(0.0)$ & $13(2.9)$ & $426(94.7)$ & $11(2.4)$ & NS & $0(0.0)$ & $12(3.5)$ & $326(93.9)$ & $9(2.6)$ & NS \\
\hline Public hospital & $1(0.1)$ & $36(7.1)$ & $705(89.9)$ & $22(2.8)$ & $*$ & $14(1.9)$ & $54(7.3)$ & $657(88.4)$ & $18(2.4)$ & $\boldsymbol{t}$ \\
\hline Midwifery home & $0(0.0)$ & 3 (1.9) & $148(93.1)$ & $8(5.0)$ & NS & $0(0.0)$ & $3(8.6)$ & $31(88.6)$ & $1(2.9)$ & NS \\
\hline Others & $I(20.0)$ & $0(0.0)$ & $4(80.0)$ & $0(0.0)$ & - & $0(0.0)$ & $O(0.0)$ & $g(100.0)$ & $0(0.0)$ & - \\
\hline Total & $5(0.1)$ & $172(4.6)$ & 3450 (92.4) & $105(2.8)$ & - & $17(0.5)$ & $173(5.2)$ & $3085(92.1)$ & $76(2.3)$ & \pm \\
\hline
\end{tabular}

NS, not significart, ${ }^{*}$ p<0.01; ${ }^{\dagger}$ p<0.001 vs. other place. ${ }^{\ddagger} p<0.05 ;{ }^{6} \mathrm{p}-10.01$ vs. 1983-1984

tion or stillbirth was 1.1\% for both periods. Mean birthweight of infants from mothers with this past history tended to increase in 1993-1994 although that of infants from mothers without the history decreased significantly (p<0.001). Proportion of LBWI from mothers with the history tended to decrease in 1993-1994, Influences of household husiness stanus on the menn binthweight were not recogrized (das not shown).

Table 2 shows the mean birthweights of single birth infants whose perents were both Japranese by gestational aye in 19831984 and 1993-1994. According to these data, mean birthweight in 1993-1994 tended to be lower than that at the corresponding age in 1983-1984 especially in lower gestational age make infants. The mean birthweight of infants who were bom before 37 weeks decreased markedly. Table 3 shows mean birthweight of single birth infants whose parents were boch Japanese by gestational age group and live birth order. The mean birthweight of first infants decreased significantly in 1993-1994 compered to 1983-1984 (p<0.01). The mean birthweights of infants decressed significantly in tirst infants who were bom before 40 weeks, in second infants bom before 37 weeks, and in third infants bom before 40 weeks ( $<<0.05$ ). The menn ages of mothers of firsh, second and thind infants increased significantly from $25.4,27.8$ and 30.4 years old in 1983-1984 to 26.3, 28.7 and 31.2 years old in 1993-1994, respectively $(p<0,0])$. The mean birthweight of male infants and, especially, of male first childen decreased significantly in 1993-1994 compared to 1983-1984 (p<0.01). The mean gestational age of second childen was lower than that of first children except for male infants bom in 1993-1994. Mean gestational age was higher in female infants than in male infants (p<0.05). Mean gestational age of first infants tended to decrease in 1993-1994.

Table $\mathbf{4}$ shows the results of stepwise regression analysis. Gestational age was the leating determinant factor in all analyses. Male infant were positively related to the birthweight. Fist infart, birth in 1993-1994 and young mother ( $\angle 20$ years old) were negatively associated with birthweight.

Table 5 shows the distribution of birthweigtu of infants by birth place. The proportion of LBWI was higher in the infents who were born in public hospitals than in those bem in clinics, private hospitals, and other places in both 1983-1984 and 1993-1994. The proportion of very low birthweight infents who were born in public hospitals increased significanty in 1993-1994. The mean birthweight of infants bocm in public hospitals was the lowest of all infants when compared with births in clinics. private hospitals, and other places. Mean birthweight of infants who were born in public hospitals decreased $56 \mathrm{~g}$ for males and $52 \mathrm{~g}$ for females in 1993-1994. and mean gestational age of those decreased 0.1 week for male and female infants in 1993-1994. Table 6 shows the distribu- 
Table 6. Numbers (\$) of infants (single births whose partents were both Japanese) by gestalional age and birth palce.

\begin{tabular}{|c|c|c|c|c|c|c|c|c|}
\hline \multirow[b]{2}{*}{ Birth place } & \multicolumn{4}{|c|}{ 1983-1984 } & \multicolumn{4}{|c|}{$1993-1994$} \\
\hline & $\leq 36$ weeks & $37-41$ weeks & 242 weeks & $x^{2} \operatorname{test}$ & $\leq 36$ weeks & 37-41 weeks & $\geq 42$ weeks & $x^{2}$ test \\
\hline Clinic & $85(3,6)$ & $2164(92.7)$ & 85 (3.6) & NS & $48(2.2)$ & $2116(95.6)$ & $49(2.2)$ & 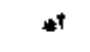 \\
\hline Privere hospital & II $(2,4)$ & $405(90.0)$ & $34(7.6)$ & $*$ & $4(1.2)$ & 338 (97.4) & $5(1.4)$ & $t$ \\
\hline Public hospital & $38(4.8)$ & $722(92.1)$ & $24(3.1)$ & NS & $48(6.5)$ & $679(91.4)$ & $16(2.2)$ & $*$ \\
\hline Midwifery home & $2(1.3)$ & $153(9.2)$ & $4(2.5)$ & NS & $1(2.9)$ & $32(91,4)$ & $2(5.7)$ & NS \\
\hline Others & $1(20.0)$ & $4(80.0)$ & $0(0.0)$ & . & $0(0.0)$ & $8(88.9)$ & $1(\mathrm{II}, 1)$ & - \\
\hline Total & $137(3.7)$ & $3448(92.4)$ & $147(3.9)$ & - & $101(3.0)$ & $3173(94.8)$ & $73(2.2)$ & + \\
\hline
\end{tabular}

NS, not significant, *p $<0.001$ vs. other place. ${ }^{*}<0.001$ vs. 1983-1984

tion of gestational age of births by birth place. The proportion of pretern infants was significantly higher in the infants who were bom in public bospitals than in these born in clinics, private hospitals, and other places in 1993-1994.

\section{Descussion}

Low birthweighe genceally nesults from preterm delivery or intrauterine growth retardation ${ }^{2,4}$. The mean birthweight of infants decreased in 1993-1994 compared to 1983-1984 although the mean gestational ages changed little (from 39.15 weeks to 39.13 weeks). The rate of birchweight increase was 62-113 g per week from 39 weels to 40 weeks. Acconding to these data, the mean birthweight in 1993.1994 should be less than $3 \mathrm{~g}$ lighter than that in 1983-1984, aldhough the mean birttweight in 1993-1994 was $37 \mathrm{~g}$ lighter than thet in 19831984. And, the mean birthweight for each gestational wek was mostly lower in 1993-1994 than in 1983-1984. From these results, in is soggested that the decrease of birthweight in 19931994 is related to intrauterine growth retandation.

The mean birthweight of infants in Japan was $3.17 \mathrm{~kg}$ in 1983 and 1984, 3.09kg in 1993, and 3.08kg in 1994". The degree of decrease in the mean birthweight was smallex in the studied area than that in Japan as a whole. The percentage of LBWI in Japan was $5.4 \%$ in 1983 and $1984,6.8 \%$ in 1993, and 7.1\% in 1994. The percentage of LBWI in the studied area was lower then in Japan. As for distribution of birth place, 55.7\% were bom in hospitals and 43.2\% in clinies in 1994 in Japen. More infants were born in clinics in the studied area than in Japan, because the number of hospital beds for pregnant wornen are fewer than that of clinic beds in the studied area.

The main causes of the mean birthweight decrease in this study were decreases in the mean birthweight of first infants and changes of the proportion of birth order. In Japan, the sumber of children per couple is decreasing; the total fertility rate has decreased from 1.91 in 1975. 101.76 in 1985, and 1.50 in 1994. In addition, the proportion of high-risk pregranky, such as higher mother's age, induction of ovulation, medical treat- ment for sterility, and conditions that need cesarean ection, is increasing because many couples want at least one child by any means. In this study, the mean age of mothers increased in 1993-1994, and 20.7\% of mothers aged 35 years and over were primiparous. Recendly, more women are bikely oo delay marrying and childbearing. It is reported that advancing maternal age (S35 years) is a risk factor for fetal death ${ }^{\text {th }}$. This study, howevex, is comstrained by the fact that it is based on data appering on the bith certificate, and this does not ixclode the important variables such as makemal smoking. The increase in the proportion of femsle smoker under 39 years of aget may be one factor contributing to the decrease of mean birthweight Influences of decrease in energy intake and those of occupational activity curing pregrancy also must be studied.

The proportion of very low birthweight infants increased in 1993-1994. Many of the very low birthweight infants now survive because neonetal intensive care is availabte, especially in large public hospitals. However, the effects of very low birthweight when these infants become adults are unknown ${ }^{202 \text { ). }}$. The lower mean birthweight of infants who were bom in public hospitals indicates that pregnant women with higher risk factors are mare likely to be referted to the care of large public hospitals with appropriate equipment. In addition, infents with greater risk factors such as very low birth weight and very preterm birth are now transferred immediately to neonasal imnensive care units in Prefectural Gifu Hospital. Efforts of the mothers with greater risk factors to have at least one child may explain part of the increase of the ratio of very low birthweights. As for programs to prevent preterm births and low bitthweight, health counseling for pregnent women is offered th $2=10$. Health counseling for pregnint women with highrrisk factors should be strengthened because most pegenant women in Japan use matemity healch services.

The propotion of mulliple birth infants increased in 19931994. The result is consistent with the trends in Japan based on the increased we of assisted reproductive technologies. Infants of multiple gestations ane more likely to be premanure and likely to be low weipht than single birth infints. However, 
the mean birthweights of multiple birth infants tended to increase in 1993-1994. These resuls indicate the contribution of medicel care and heallh services for pregnint women.

Changes of pencentage distribution of birth place over the 10-year period reflect the mends that most pregnant women are placed under management by obstetricians, primarily in clinics and secondarily in large public hospitals although pregnant women can consult directly for secondary hospitials in Japan. The ratio of nonhospitalized births in Japan decreased from $82.4 \%$ in 1955 to $16.0 \%$ in $196,1.2 \%$ in $1975,0.2 \%$ in 1985 , and $0.1 \%$ in $1994^{10}$. The ratio of births at midwife hormes in Jepen also decreased from $12.9 \%$ in 1965 to $7.2 \%$ in 1975 , $2.0 \%$ in 1985 , and $0.9 \%$ in 1994 .

As for gestational age, the percentage of births at less than 38 weeks and 42 weeks or more decreased in 1993-1994. These results also indicate the effects of medical management. Decrease of the percentage of posttem labor contributes to the decrease in mean birthweight. The author imerpreted that the decrease of postierm labor is a nesult of active management of labor for highly posterm pregnant wormen ${ }^{20}$.

The decrease of the mean birthweight of infants resulted mainly from the decrease of the mean birthweight of first infants, some of whom were bom to mothers with risk factors. Antenatal health guidance to prevent toxemia of pregnancy and medical induction of delivery to avoid posterm lator or cesurean section as an iarogenic effect may contribute to the docrease in the mean binthweight.

\section{REFRAGNES}

1. Ministry of Health and Welfare, Japan. Vital Statistics of Japen, 1994, Volume 2. Health and Welfare Statistics Association, Tokyo, 1996: 116-232.

2. Villar J, Belizan JM. The relative contribution of prematurity and fetal growth retardation to low birth weight in developing and developed societies. Am J Obstet Gynecol, 1982; 143: 793-798.

3. Kramer MS. Deterninants of low birth weight methodological assesment and meta-malysis. Bull WHO, 1987; 65: 663-737.

4. Fectrick J, Adelstein P. Factors associated with low bith weight of infants delivered at term, Br J Obstet Gynaeod, 1978; 85: 1-7.

5. Eisner V, Brazie JV, Pratt MW, Hexter AC. The risk of low bi,th weight. Am J Public Health, 1979; 69, 887-893.

6. Simpson WJ. A preliminary report on cigarette smoking and the incidence of prematurity. Am J Obstet Gynecol. 1957; 73: 808-815.

7. Fox SH, Koepsell TD, Daling JR. Birth weight and smoking during pregnancy - effect modification by maternal age. Am J Epidemiol, 1994; 139، 1008-1015.

8. Berkowitz GS, Papiemik E. Epidemiology of pretem birth. Epidemiol Rev, 1993; 15: 414-443.

9. Naeye RL. Weight gain and outcome of pregnancy. Am J Obstet Gynecol, 1979; 135: 3-9.

10. Takeda S, Saitoh M, Kinoshita K. Sakamoto S. Studies of diet management and insulin resistance in obese pregnant women. Acta Obstret Gynecol Jph, 1992; 44: 229-236.

11. Ministry of Health and Welfare, Japan, ed. Byoin Yoran, 1983 [Hospital directory in Japan, 1983]. [gaku-shoin, Tokyo, 1983; pp.5-368.

12. Ministry of Health and Welfare, Japan, ed. Byoin Yoran, 1993 [Hospital dinectory in Japan, 1993]. Igaku-shoin, Tokyo, 1993: 1-569.

13. Lieberman E, Ryan KJ, Monson RR, Schoenbaum SC. Risk factors accounting for racial differences in the rite of premature bith. N Engl J Med, 1987; 317: 743-748.

14. Kleinman JC, Kessel SS. Racial differences in low birth weight. N Engl J Med, 1987; 317: 749-753.

15. Singh GK, Yu SM. Birthweight differentials among Asian Americans Am I Public Health, 1994; 84: 1444-1449.

16. Mochers' and Children's Health and Welfare Association. Maternal and Child Health Statistics of Japan, 1995. Mothers' and Children's Health Organization. Tokyo, 1996: 18-132.

17. Fretts RC. Schmittdiel J, McLean FH, Usher RH, Goldman MB. Increased maternal age and the risk of fetal death. N Engl J Med, 1995: 333: 953-957.

18. Nishimura C, Nakayama T. Nalkayanna N, Tsuguma $H$, Suzuki R. Time-tiends of smoking hahit by age, sex and birth year - Observations among participants in mass screening for lung cancer in Osaka, Japan. Jpon J Public Healch, 1996; 43: 1063-1067.

19. Matsuda S, Sone T, Doi T, Kahyo H. Secular changes of the mean birth weight and the mean gestational day at an obstetric clinic in Nath Jpn J Hyg, 1990; 45: 665-679.

20. MoConmick MC. The contribution of low birth weight to infamt mostality and childhood mortidity. N Engl J Med. 1985; 312: 82-90.

21. Breslau N. Psychiatric sequelae of low birth weight. Epidemiol Rev, 1995; 17: 96-106.

22. Gontmaker SL. The effects of prenatal care upon the health of the newborn. Am J Public Health, 1979; 69: 653-660.

23. Rautava P. The Firmish family competence study: characteristics of pregnant women with low child birth knowledge. Soc Sci Med, 1989, 24, 1105-1109.

24. Alexander GR, Mor JM, Kogan MD, Leland NL, Kiefter E. Pregnancy outcomes of US-born and foreign-bom Japanese Americans. Am J Public Health, 1996; 86; 820824.

25. Frigoletto FD Jr, Lieherman $E$, Lang $\mathbf{M}$, Cohen $A$, Barss $V$, Ringer $S$, et al. A clinical trial of active management of labor. N Engl J Med, 1995; 333: 745-750. 